\title{
Mexican conifers differ in their capacity to face climate
} change

\author{
C. Sáenz-Romero ${ }^{1,2}$, M. Larter², N. González-Muñoz ${ }^{2}$, C. Wehenkel ${ }^{3}$, A. Blanco-Garcia ${ }^{4}$, D. \\ Castellanos-Acuña $^{1,5}$, R. Burlett ${ }^{2}$ and S. Delzon ${ }^{2}$
}

${ }^{1}$ Universidad Michoacana de San Nicolás de Hidalgo, Instituto de Investigaciones Agropecuarias y Forestales (UMSNH-IIAF). Km 9.5 Carretera Morelia-Zinapécuaro, Tarímbaro Michoacán 58880, México; ${ }^{2}$ Institut National de la Recherche Agronomique (INRA), Unité Mixte de Recherche 1202 Biodiversité Gènes \& Communautés (UMR 1202 BIOGECO), F-33610 Cestas, France \& Université de Bordeaux, F-33615 Pessac, France; ${ }^{3}$ Instituto de Silvicultura e Industria de la Madera, Universidad Juárez del Estado de Durango, Aptdo. Postal 741 Zona Centro, Dgo., C.P. 34000, México; ${ }^{4}$ Facultad de Biología, Universidad Michoacana de San Nicolás de Hidalgo, Av. Francisco J. Mújica s/n, Col. Felícitas del Río, Morelia Michoacán 58040, México; ${ }^{5}$ Department of Renewable Resources, Faculty of Agricultural, Life, and Environmental Sciences, University of Alberta, 733 General Services Building Edmonton, AB, T6G 2H1, Canada.

Corresponding author: Cuauhtémoc Sáenz-Romero, csaenzromero@gmail.com

Date of submission: $24 / 03 / 2016$

Date of publication: $24 / 01 / 2017$

\begin{abstract}
The recent massive dieback of forest trees due to drought stress makes assessment of the variability of physiological traits that might be critical for predicting forest response and adaptation to climate change even more urgent. We investigated xylem vulnerability to cavitation and xylem specific hydraulic conductivity in seven species of three principal conifer genera (Juniperus monticola, Juniperus deppeana, Juniperus flaccida, Pinus pseudostrobus, Pinus leiophylla, Pinus devoniana, and the endangered Picea chihuahuana) of the Mexican mountains in order to identify the species most vulnerable to future warmer and drier climates. Hydraulic traits were examined using the in situ flow centrifuge technique (Cavitron) on branches collected from adult trees of natural populations and seedlings growing in a common garden. We found evidence of significant differences in xylem safety between genera $\left(P_{50}\right.$ : pressure inducing $50 \%$ loss of hydraulic conductance): the three juniper species exhibited low $P_{50}$ values (ranging from -9.9 to $-10.4 \mathrm{MPa}$ ), relative to the much more vulnerable pine and spruce species $\left(P_{50}\right.$ ranging between - 2.9 to - 3.3 MPa). Our findings also revealed no variation in $\boldsymbol{P}_{50}$ between adult trees assessed in the field and seedlings growing in a common garden. We therefore propose that if, as projected, climate change makes their natural habitats much warmer and drier, populations of Mexican pines and the studied spruce will be likely to decline severely as a result of droughtstress induced cavitation, while the juniper species will survive.
\end{abstract}

\section{Introduction}

Concerns are increasing because of the mounting evidence of forest decline related to drought stress, apparently linked to ongoing climatic change (Breshears et al., 2005; Peñuelas et al., 2007; Mátyás, 2010; Allen et al., 2010). Hotter drought periods are inducing massive tree mortality (Allen et al., 2015) and, by year 2050, there is likely to be a substantial reorganization of vegetation (McDowell and Allen, 2015), with a plant community composition unfamiliar to modern civilization (Williams et al., 2013). In such a context, the study of variation among and within forest species in terms of cavitation resistance is very important in order to predict the potential of adaptation to climatic change (Choat et al., 2012). Resistance to cavitation has been shown to be a good estimator of tolerance to drought in vascular plant species (Brodribb and Cochard, 2009; Brodribb et al., 2010). Previous studies have reported the high variability of $\mathrm{P}_{50}$ (a proxy of cavitation resistance, corresponding to the xylem pressure inducing a 50\% loss of hydraulic conductance) among conifer species, ranging from -3 to -19 MPa (Delzon et al., 2010; Pittermann et al., 2010; Larter et al., 2015).

There are indications that many forest tree species possess a very narrow hydraulic safety margin $(<1 \mathrm{MPa})$ and therefore they will potentially face long-term reductions in productivity and survival in a drier world (Choat et al., 
2012). However, large differences in hydraulic safety margins have been observed among species growing in the same habitat and one species can therefore be favored over another under certain conditions (Breshears et al., 2005; Urli et al., 2015). Conifers of genera Juniperus, Picea and Pinus frequently co-occur in the highly biodiverse Mexican mountains (Quiñones-Perez et al., 2014; Figure 1), since they share similar climatic habitat conditions. Previous studies of cavitation resistance in conifer forest communities of southwestern USA (Arizona, New Mexico, Utah and Colorado states, Breshears et al., 2005) have shown large differences in $P_{50}$ values between Pinus edulis and Juniperus monosperma, even where both species co-occur in that region.

The differences among conifer genera and species for cavitation resistance sharing similar climatic habitats have not been explored for Mexico in great detail, despite the very wide biodiversity of conifers in Mexico (Styles 1993). A previous study, focused on differences within Pinus hartwegii along an altitudinal gradient, showed no populationlevel genetic differentiation for cavitation resistance (Sáenz-Romero et al., 2013). That trend is consistent with much broader studies that indicate remarkably low variation among populations within conifer species (i.e. Pinus pinaster, Lamy et al., 2011). At the genus level, pines and spruces seem to be moderately resistant to cavitation $\left(P_{50}:-3\right.$ to -4.7 $\mathrm{MPa}$ and -3.7 to $-5.2 \mathrm{MPa}$, respectively; Bouche et al., 2014). This pattern contrasts strongly with the more cavitationresistant genus Juniperus (Cupressaceae) that also shows much more variation across species, with $\mathrm{P}_{50}$ values ranging from around -6 to -14 MPa (Bouche et al., 2014; Willson et al., 2008).

In the present study, we aim to assess differences in hydraulic safety (drought-induced cavitation resistance) and conductivity (water-transport efficiency) among seven Mexican conifer species belonging to three genera: Juniperus, Pinus and Picea. Some of these frequently co-occur in the highly biodiverse Mexican mountains (Quiñones-Perez et al., 2014; Figure 1) and thus share similar climatic habitat conditions. The mountain conifer forests of Mexico are expected to experience a drier climate with more frequent droughts, which may lead to a $92 \%$ loss of their suitable climatic habitat along the Trans-Mexican Volcanic Belt by the end of this century (Rehfeldt et al., 2012). Under this scenario, we hypothesize highly species-specific responses, with a high risk of mortality for species of greater vulnerability to cavitation as a response to drought events.

\section{Materials and Methods}

\section{Study area and study species}

We focused on seven conifer species, six of which occur across a wide altitudinal gradient along the central Mexican mountains (Trans-Mexican Volcanic Belt, TMVB) and one in the Sierra Madre Occidental (Figure 1). The species were:

(a) Three juniper species: Juniperus monticola (high elevation, cold and humid environments, including sites within the Monarch Butterfly Biosphere Reserve overwintering sanctuaries), J. deppeana (intermediate elevations between 2200-2900 m a.s.l., temperate climate, occurring in the pine-oak forest, wide distribution in Mexico) and $J$. flaccida (occurring at lower elevations, in environments with marked drought/rainy seasonality and savanna-like vegetation with frequent natural or induced fires, at the lowest altitudinal distribution of the genus in the studied region, overlapping with the upper altitudinal limit of the tropical dry forest) (Carranza and Zamudio, 1994).

(b) Three pine species, selected among the most abundant pine species of the pine-oak forest at the TMVB in Michoacán state, with partially altitudinal overlapping distributions: Pinus pseudostrobus (intermediate to high elevations, the most abundant and economically important species), $P$. leiophylla (intermediate altitudes, appearing on poorer sites than P. pseudostrobus) and $P$. devoniana (low altitudinal limit of the pine-oak forest, close to the upper altitudinal limit of the tropical dry forest). The distributions of the three pine species overlap at the mid-altitudinal range of the pine-oak forest, approximately at 2200 to $2300 \mathrm{~m}$ asl in altitude (Castellanos-Acuña et al., 2015; Table 1)

(c) A very rare, endangered, endemic spruce, Picea chihuahuana, with fragmented and endogamic populations, occurring at high elevations, at the cold and humid sites of the Sierra Madre Occidental, in northwestern Mexico. Picea chihuahuana is the most abundant spruce among the only three species of this genus that exists in Mexico (the others are Picea martinezii and P. mexicana), where spruces are postglacial relicts (Ledig et al., 2010; Wehenkel and Sáenz-Romero, 2012; IUCN 2015). 

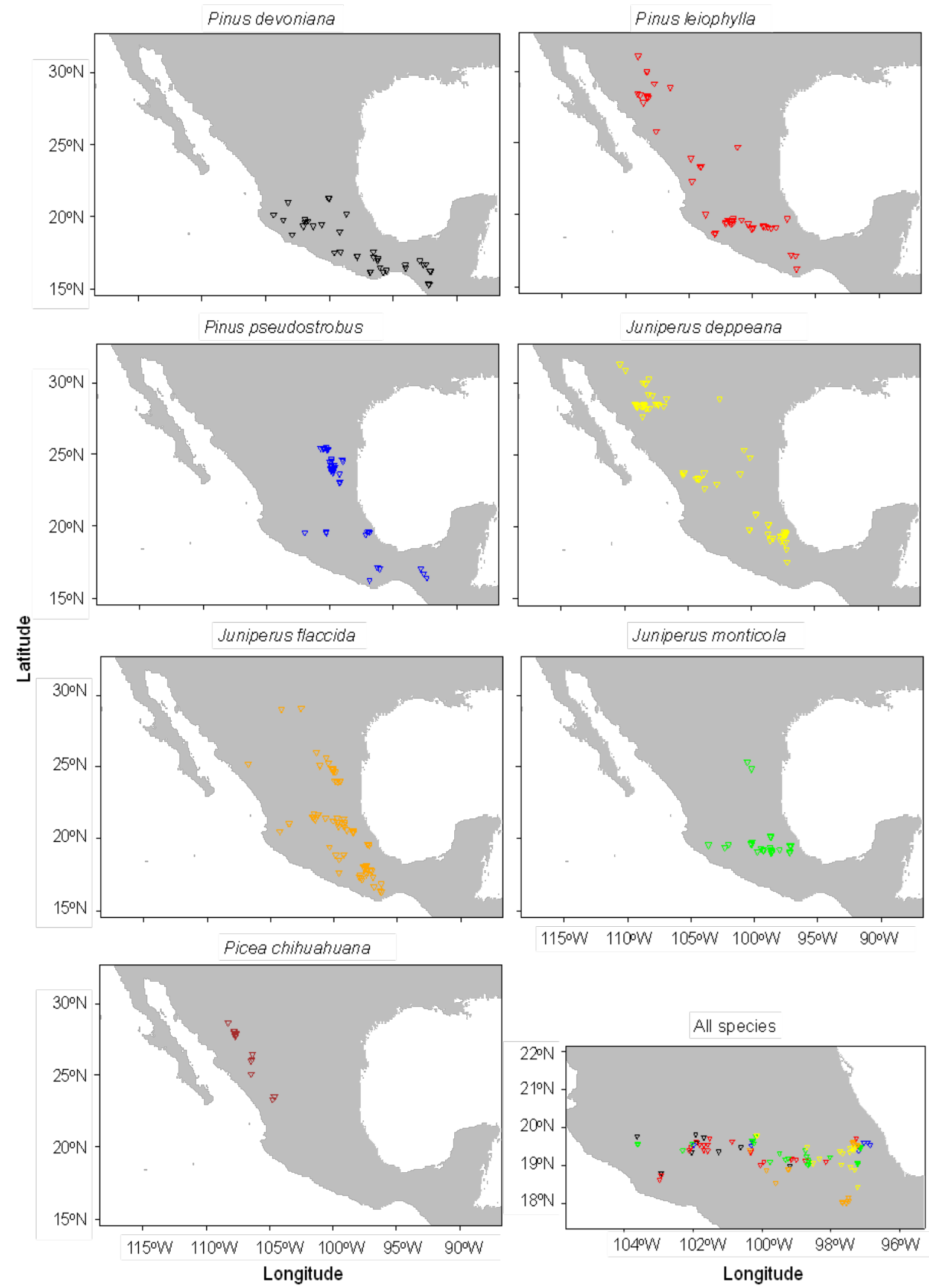

\section{Figure 1. Distribution of the seven studied conifers in Mexico.}

Sites correspond to plots recorded by the Mexican National Forest Inventory, for which climatic and aridity index data are available from http://www.worldclim:bioclim and http://www.cgiar-csi:data/global-aridity-and-pet-database, respectively. The final insert shows a close-up of the Trans-Mexican Volcanic Belt. 


\section{Sampling procedures}

Drought-induced resistance to cavitation and hydraulic conductivity were evaluated in branches collected from natural populations of the seven conifer species studied. For each juniper species, we collected branches of seven to eight trees belonging to one population representative of the distribution range of the species, in zones with high conifer diversity (Table 1). For each pine species, six to seven trees from two to four populations were collected, aiming to represent the altitudinal distribution range of each species (Table 1). Fifteen individuals were sampled from Picea chihuahuana Santa Barbara population (also known as Arroyo El Infierno; Ledig et al., 2000), at a high elevation (2725 m a.s.1.) site of the Sierra Madre Occidental, Durango State, in northwestern Mexico.

As a complementary sampling to explore variability in hydraulic traits within species, we collected branches of the three pine species from individuals growing in a common garden test at Morelia, Michoacán (Lat. 19.69 N, Lon. $101.25 \mathrm{~W}$, altitude $1.900 \mathrm{~m}$ a.s.l.). These trees were grown from seeds obtained from natural populations of the same pine species and region, aiming to represent the altitudinal gradient on which each species occur. However, due to the minimum branch size requirement for xylem cavitation analysis (see details below), only a reduced number of individuals were sampled: two to five seedlings (exceptionally one seedling, in one case) from two populations of each pine species (Table 1). This additional common garden sampling was not possible for the rest of the species studied here, as provenance tests were unavailable. The site of the common garden test has a much warmer and drier climate (mean annual temperature $17.0{ }^{\circ} \mathrm{C}$, mean annual precipitation $871 \mathrm{~mm}$ ) than that of the sites of the studied natural populations (although watering was provided when required in order to ensure seedling survival).

Table 1. Population origin of the branch samples analyzed for cavitation, either from collection of field samples, or from populations represented in a common garden test.

With the exception of Picea chihuahuana, collected in Durango state (Dgo.), northwestern Mexico, all others come from Michoacán state (Mich.), central-western Mexico. Sample size indicates the number of trees from which samples were collected.

\begin{tabular}{|c|c|c|c|c|c|c|}
\hline \multirow[t]{2}{*}{ Locality and State } & \multirow{2}{*}{$\begin{array}{c}\text { Elevatio } \\
n \\
\text { (m a.s.1.) }\end{array}$} & \multirow[t]{2}{*}{ Lat $(\mathrm{N})$} & \multirow[t]{2}{*}{$\begin{array}{l}\text { Lon } \\
\text { (W) }\end{array}$} & \multirow[t]{2}{*}{ Species } & \multicolumn{2}{|c|}{$\begin{array}{l}\text { Sample size } \\
\text { (individuals) }\end{array}$} \\
\hline & & & & & Field & $\begin{array}{l}\text { Commo } \\
\text { n garden }\end{array}$ \\
\hline Santa Bárbara, Dgo. & 2.725 & 23.66 & 105.44 & Picea chihuahuana & 15 & - \\
\hline Sierra Chincua, Mich. & 3.142 & 19.65 & 100.25 & Juniperus monticola & 8 & - \\
\hline Tlalpuhahua, Mich. & 2.575 & 19.80 & 100.17 & Juniperus deppeana & 8 & - \\
\hline Tuxpan, Mich. & 1.870 & 19.60 & 100.48 & Juniperus flaccida & 7 & - \\
\hline Cerro Pario (High), Mich. & 2.746 & 19.47 & 102.18 & Pinus pseudostrobus & 6 & - \\
\hline Cerro Pario (Int.), Mich. & 2.600 & 19.47 & 102.19 & Pinus pseudostrobus & 7 & - \\
\hline Cerro Pario (Low), Mich. & 2.520 & 19.46 & 102.20 & Pinus pseudostrobus & - & 3 \\
\hline La Pila (High), Mich. & 2.422 & 19.45 & 102.18 & $\begin{array}{l}\text { Pinus pseudostrobus } \\
\text { Pinus leiophylla }\end{array}$ & $\begin{array}{l}7 \\
7\end{array}$ & $\begin{array}{l}- \\
-\end{array}$ \\
\hline La Pila (Low), Mich. & 2.310 & 19.44 & 102.17 & $\begin{array}{c}\text { Pinus pseudostrobus } \\
\text { Pinus leiophylla } \\
\text { Pinus devoniana }\end{array}$ & $\begin{array}{l}- \\
6 \\
-\end{array}$ & $\begin{array}{l}3 \\
2 \\
5\end{array}$ \\
\hline El Rosario (High), Mich. & 2.217 & 19.43 & 102.17 & $\begin{array}{l}\text { Pinus leiophylla } \\
\text { Pinus devoniana }\end{array}$ & - & $\begin{array}{l}2 \\
-\end{array}$ \\
\hline El Rosario (Int.), Mich. & 2.110 & 19.43 & 102.16 & $\begin{array}{l}\text { Pinus leiophylla } \\
\text { Pinus devoniana }\end{array}$ & $\overline{6}$ & $\begin{array}{l}2 \\
1\end{array}$ \\
\hline El Rosario (Low), Mich. & 2.034 & 19.42 & 102.15 & Pinus devoniana & 7 & - \\
\hline Jicalán, Mich. & 1.650 & 19.38 & 102.08 & Pinus devoniana & 6 & - \\
\hline
\end{tabular}

\section{Sample processing}

Branches were collected early in the morning to avoid high temperatures and all needles were immediately removed to prevent desiccation. The samples were then wrapped in wet paper towels, placed in black bags, and immediately posted to France for analysis. Vulnerability to drought-induced cavitation was determined, at the high-throughput phenotyping platform for hydraulic traits (CavitPlace, University of Bordeaux, Talence, France; http://sylvaindelzon.com/caviplace). The samples were kept wet and cool $\left(3^{\circ} \mathrm{C}\right)$ until cavitation resistance was measured within three weeks of collection. Prior to measurement, all branches were cut with a razor blade under water to a standard length of $27 \mathrm{~cm}$, the bark was removed and they were fully rehydrated before further processing. 


\section{Measurement of resistance to cavitation}

Xylem cavitation was assessed with the CAVITRON, a flow centrifuge technique, following the procedure described in Cochard (2002) and Cochard et al., 2005. In the CAVITRON, a centrifugal force establishes a negative xylem pressure, inducing a loss of conductance by cavitation. Samples are inserted into a custom-built rotor (Precis 2000, Bordeaux, France) mounted on a high-speed centrifuge (Sorvall RC5, USA). Xylem pressure ( $\left.\mathrm{P}_{\mathrm{i}}\right)$ is first set to a reference pressure $(-0.5 \mathrm{MPa})$ and hydraulic conductivity $(k i)$ is determined by measuring the flux through the sample. The centrifugation speed is then set to a higher value for 3 minutes to expose the sample to more negative pressure.

The conductance was measured three to four times, and the average was used to compute the percentage loss of xylem conductance (PLC in \%) at that pressure (see Delzon et al., 2010 for details). This procedure was repeated for at least eight pressure steps with a -0.5 MPa step increment until the PLC reached at least 90\%. Rotor velocity was monitored with a $10 \mathrm{rpm}$ resolution electronic tachymeter and xylem pressure was adjusted to about $-0.02 \mathrm{MPa}$. Conductance measurements were taken using the Cavisoft software (version 2.0, BIOGECO, University of Bordeaux).

Percentage loss of conductance in the xylem as a function of xylem pressure ( $\mathrm{MPa}$ ) represents the vulnerability curve (VC) of the sample. A standard sigmoid function (Pammenter and Van der Willigen, 1998; Cochard et al., 2005) was fitted to the VC of each sample, using SAS v 9.1 (SAS Institute 2004) and the following equation:

$$
P L C=\frac{100}{1+e^{\left(\frac{S}{25} *\left(P-P_{50}\right)\right.}}
$$

where $\mathrm{P}_{50}(\mathrm{MPa})$ is the xylem pressure that induces $50 \%$ loss of conductance and $S\left(\% \mathrm{MPa}^{-1}\right)$ is the slope of the vulnerability curve at the inflexion point. The specific hydraulic conductivity $\left(k_{s}, \mathrm{~m}^{2} \mathrm{MPa}^{-1} \mathrm{~s}^{-1}\right)$ of the xylem was calculated by dividing the maximum hydraulic conductivity measured at low speed by the sapwood area of the sample.

More negative $P_{50}$ (xylem pressure inducing 50\% loss of conductance) values indicate higher resistance to cavitation, while the slope of the vulnerability curve $(\mathrm{S})$ indicates how fast cavitation progresses at $\mathrm{P}_{50}$.

\section{Statistical analysis}

We tested differences in xylem pressure inducing 50\% loss of conductance $\left(P_{50}\right)$, slope of the vulnerability curve at the inflexion point $(S)$ and xylem specific hydraulic conductivity $\left(k_{s}\right)$ among species and genera by conducting a twoway nested ANOVA followed by a post-hoc Tukey test $(\alpha=0.05)$. The ANOVAs were performed using the Procedure GLM of SAS (SAS Institute, 2004). Variance components were estimated using the Procedure VARCOMP with the method of restricted maximum likelihood (REML) of SAS (SAS Institute, 2004).

In order to find possible evolutionary associations between increasing cavitation resistance and increasing aridity, we conducted a regression analysis between the means of the hydraulic traits of each species (all species, field data only) against the median of three climate variables along each species distribution range: Mean Annual Temperature (MAT), Mean Annual Precipitation (MAP), Annual Aridity Index (AAI: Mean Annual Precipitation/ Mean Annual Potential Evapotranspiration). We also regressed the means of the hydraulic traits of each species against the extreme values of the climatic variables, calculated as the median of the 5\% of highest MAT (MAT_max), lowest MAP (MAP_min) and more arid AAI (AAI_max) values. Climatic and aridity index values averaged per species were estimated from presence points covering the full distribution range of the species (illustrated on Figure 1 for Mexico) and obtained from http://www.worldclim:bioclim and http://www.cgiar-csi:data/global-aridity-and-pet-database, respectively. For Juniperus and Pinus genera, we explored the relationship between the intraspecific variability in hydraulic traits and the climate of each population by regressing the means per population against the provenance climate variables for those two genera.

In the specific case of the genus Pinus, we also explored the plasticity in hydraulic safety and conductivity. To do so, we compared the $\mathrm{P}_{50}, S$ and $k_{s}$ of field versus common garden samples using a two-way ANOVA, in which the species and the study (field/common garden) were included as factors. 


\section{Results}

\section{Differences among genera and species}

Hydraulic traits varied widely across the studied species, with $\mathrm{P}_{50}$ values ranging from $-2.94 \mathrm{MPa}$ (Pinus pseudostrobus) to $-10.37 \mathrm{MPa}$ (Juniperus monticola). The slope of the vulnerability curve varied from extremely steep $\left(87.78 \% \mathrm{MPa}^{-1}\right.$ for Pinus leiophylla) to very flat (i.e. less than $20 \% \mathrm{MPa}^{-1}$ for each juniper species).

Most of this variation occurred at the genus level since, for example, juniper $\mathrm{P}_{50}$ was on average about $7 \mathrm{MPa}$ more negative than the pine and spruce $\mathrm{P}_{50}$ values (see Figure 2). Similarly, we found large differences in the slope of the vulnerability curve at the inflexion point $(S)$ between the juniper species in comparison to the pines and the spruce. The three Pinus species had $S$ values well above $50 \% \mathrm{MPa}^{-1}$, Picea chihuahuana was close to this (47), but the Juniperus species had $S$ values of between 16 and 20 . We evidenced significant differences among genera in $\mathrm{P}_{50}$ (xylem pressure inducing 50\% loss of conductance, $\mathrm{P}<0.0001$ ) and $S$ (slope of the vulnerability curve at the inflexion point, $\mathrm{P}=0.0013)$. Differences among genera explained $98 \%$ and $67 \%$ of the total variation for $\mathrm{P}_{50}$ and $S$, respectively (Table 2). In contrast, differences between species within genera accounted for a marginal $0.2 \%$, and $1.9 \%$ for $\mathrm{P}_{50}$, and $S$, respectively (Table 2 ).

Xylem transport efficiency, $k_{s}$, varied from $0.0003 \mathrm{~m}^{2} \mathrm{MPa}^{-1} \mathrm{~s}^{-1}$ for Picea chihuahuana to $0.0021 \mathrm{~m}^{2} \mathrm{MPa}^{-1} \mathrm{~s}^{-1}$ for Pinus leiophylla (17\% of the total variation is explained by the species), but no significant differences among genera were found for this trait $(\mathrm{P}=0.066)$.

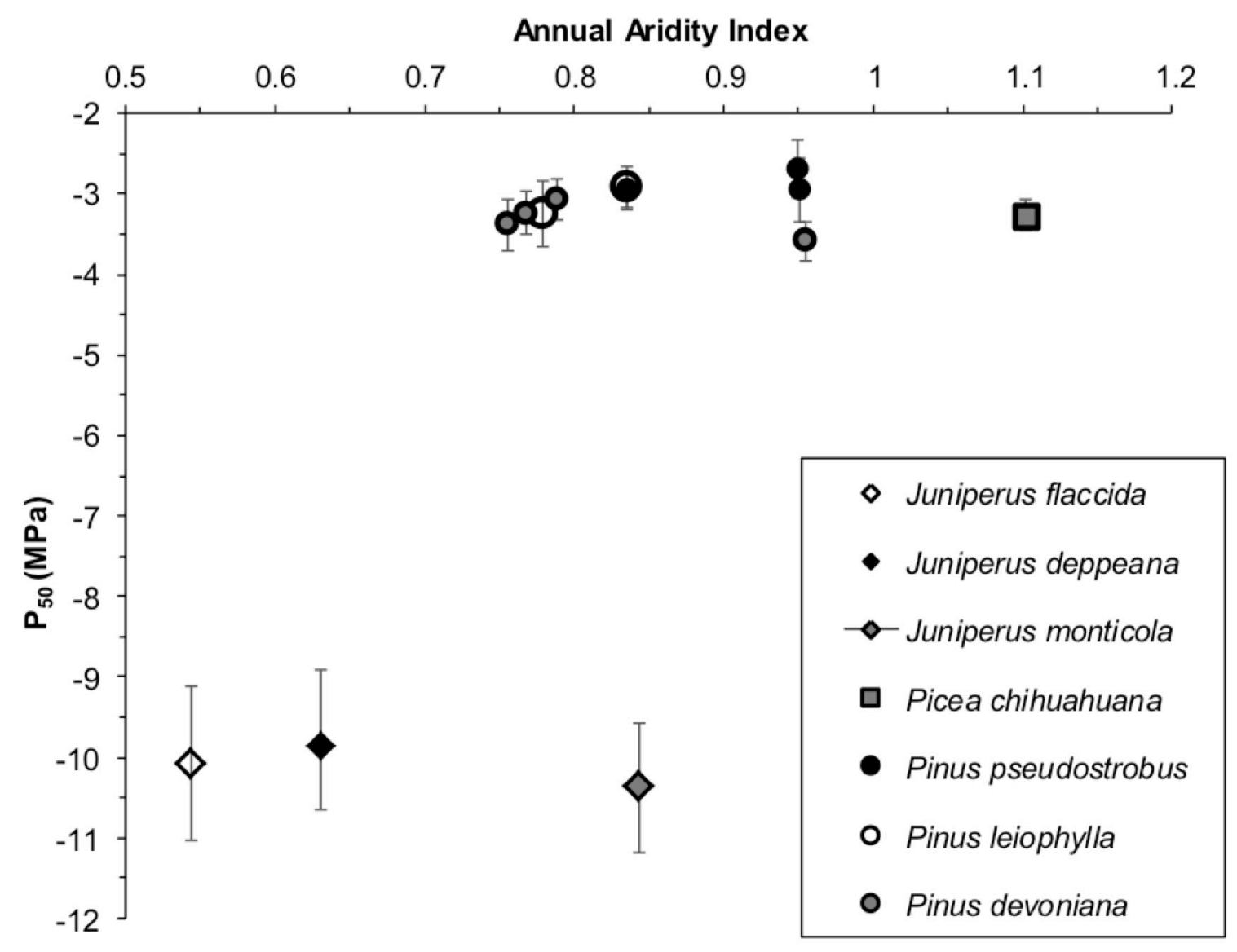

Figure 2. Xylem pressure inducing $50 \%$ loss of hydraulic conductance $\left(\mathrm{P}_{50}\right)$ in MPa.

$\mathrm{P}_{50}$ is plotted against the Annual Aridity Index median per species and per population (larger values indicate colder and more humid; smaller values indicate warmer and drier environments). Vertical bars represent $95 \%$ confidence intervals

\section{Association with climatic variables}

There is a complete lack of association between $P_{50}, S$ and $\mathrm{k}_{\mathrm{s}}$ and the six climatic variables (regression: $\mathrm{r}^{2}<0.03 ; \mathrm{P}>$ 0.20). Notice on Figure 2 that Juniperus monticola, despite growing in much less arid (more cold and humid) sites than all of the pines and the spruce, shows a $\mathrm{P}_{50}$ similar to that of Juniperus deppeana and J. flaccida, which grow in the warmest and driest sites of this study. Similarly, we found no significant relationship between the hydraulic traits and climate of each population at the genus level (Juniperus and Pinus; P > 0.30). 


\section{Differences between field and common garden tests}

There were no significant differences between the values of the hydraulic traits obtained from trees in the field and common garden tests, denoting a lack of phenotypic variability in the traits measured within species (Table 2). Differences among studies account for a meaningless $0.0 \%, 0.9 \%$ and $0.0 \%$ of the total variation for $P_{50}, S$ and $k_{s}$, respectively (non-significant; $\mathrm{P}>0.45$; Table 2). Figure 3 shows how similar are the $P_{50}$ values among studies and also among pine species.

\section{Table 2. Analysis of variance}

Analysis of variance (\% of contribution to total variance and $\mathrm{P}$, significance) of xylem cavitation resistance traits $\left(\mathrm{P}_{50}\right.$, xylem pressure inducing $50 \%$ loss of conductance and $S$, slope of the vulnerability curve at the inflexion point) and xylem transport efficiency ( $k_{s}$, xylem specific hydraulic conductivity). Analyses were conducted: (a) comparing among genera from branches collected from natural populations (three species of Juniperus monticola, three Pinus and one Picea) and (b) comparing among studies (field vs. common garden) only for Pinus species. Origin of samples as in Table 1.

\begin{tabular}{|c|c|c|c|c|c|c|c|}
\hline & \multirow[b]{2}{*}{ df } & \multicolumn{2}{|l|}{$\mathrm{P}_{50}$} & \multicolumn{2}{|l|}{$S$} & \multicolumn{2}{|l|}{$k_{s}$} \\
\hline & & $\%$ & $\mathrm{P}$ & $\%$ & $\mathrm{P}$ & $\%$ & $\mathrm{P}$ \\
\hline \multicolumn{8}{|c|}{ a) All species, only field samples } \\
\hline Genus & 2 & 97.9 & $<0.0001$ & 67.3 & 0.0013 & 45.6 & 0.0661 \\
\hline Species (Genus) & 4 & 0.2 & 0.0483 & 1.9 & 0.1516 & 16.9 & $<0.0001$ \\
\hline Residual & 88 & 1.9 & & 30.8 & & 37.6 & \\
\hline Total & 94 & 100.0 & & 100.0 & & 100.0 & \\
\hline \multicolumn{8}{|c|}{ b) Only Pinus species, field $v s$. common garden } \\
\hline Study & 1 & 0.0 & 0.7475 & 0.9 & 0.5457 & 0.0 & 0.4524 \\
\hline Species & 2 & 0.0 & 0.7957 & 0.0 & 0.9145 & 17.0 & 0.2763 \\
\hline Study* Species & 2 & 21.5 & 0.0044 & 8.5 & 0.0207 & 9.2 & 0.1484 \\
\hline Residual & 70 & 78.5 & & 90.5 & & 73.8 & \\
\hline Total & 75 & 100.0 & & 100.0 & & 100.0 & \\
\hline
\end{tabular}

\section{Discussion}

\section{Large differences among genera}

We evidenced here that the three juniper species studied are much more resistant to cavitation than the three cooccurring pine species and the Chihuahua spruce examined: $P_{50}$ values of Juniperus monticola, $J$. deppeana, and $J$. flaccida were three times more negative than those of Picea chihuahuana, Pinus devoniana, P. leiophylla and $P$. pseudostrobus. Similar differences have been reported among other juniper and pine species that grow in same or similar environments (Linton et al., 1998) and with previous studies focused in species of these two genera (Delzon et al., 2010; Bouche et al., 2014). Although Picea chihuahuana was the only Picea species examined here, its $P_{50}$ value (- $3.3 \mathrm{MPa}$ ) was very close to those reported for other species of this genus (Delzon et al., 2010, Bouche et al., 2014; Nolf et al., 2015). Regarding the slope of the cavitation curve, Delzon et al., 2010 suggested that slopes $>50 \% \mathrm{MPa}^{-1}$ indicate a very fast rate of embolism. According to our results, the three pines and Picea chihuahuana had much larger slope mean values than those of the Juniperus species, confirming the greater vulnerability to cavitation in the pine and spruce species compared to the juniper species. These differences can be linked to an evolutionary divergence in hydraulic strategies within conifers when faced with drought (Brodribb et al., 2014).

\section{Lack of correlation with climate and conservatism within genera}

We did not find significant correlations between hydraulic safety $\left(P_{50}, S\right)$ and efficiency traits $\left(k_{s}\right)$ and climate variables, indicating a trait conservatism within genera. For example, $J$. monticola, which grows in the wettest conditions, shows a $P_{50}$ similar to that of $J$. flaccida, which grows in the driest environments. This result contrasts to previous studies that report positive correlations between $P_{50}$ and MAP or MAT (Maherali et al., 2004; Choat et al., 2012) and suggest evolutionary associations between increasing cavitation resistance and increasing aridity across functional groups of conifers. However, our results must be treated with some caution since not all of the regions occupied by each species are represented in the populations sampled. 


\section{Lack of phenotypic variability}

For the Pinus genus, we found no effect of the study, between samples collected from adult trees in natural populations (field) and from seedlings growing in a common garden, in any of the studied hydraulic traits. This low variability has already been observed in pinaceae species. For instance, Lamy et al., 2014 reported no phenotypic variability in $P_{50}$ between maritime pine populations in Europe. On the contrary, Martinez-Vilalta et al., 2009 found a significant between-population variability in Scots pine, with no link to climatic dryness, Very recently, DavidSchwartz et al., 2016 reported a significant genetic differentiation between Aleppo pine provenances growing in common garden. Overall, the intra-specific variation in cavitation resistance is much smaller in conifers than in angiosperms (Anderegg, 2014). Taken in conjunction, these studies highlight the fact that more research is needed, especially to quantify the phenotypic plasticity of those traits by conducting reciprocal transplant experiments.

\section{Implications for climate change adaptation}

These results (high vulnerability to cavitation and lack of phenotypic variability for pines) suggest a potential droughtinduced mortality of pine species with respect to that of Juniperus, under the warmer and drier environments predicted for Mexican regions in this century (Sáenz-Romero et al., 2010; Rehfeldt et al., 2012). When species of these two genera co-occur in the same habitats, the pine species more vulnerable to cavitation may show a much narrower safety margin and face a consequently higher risk of hydraulic failure. This has taken place already in the semiarid woodland communities of Utah, Colorado, Arizona and New Mexico, USA, where two consecutive dry and warm years (2000 to 2003) induced a massive forest decline of Pinus edulis, while Juniperus monosperma survived (Breshears et al., 2005). In Mexico, however, some Juniperus can occur in much drier habitats than pines and can therefore experience much lower minimum water potential, leading to a reduced safety margin. To confirm this, water potential would have to be measured during a dry season. However, recent studies show a strong correlation between $P_{50}$ and mortality (not only in safety margin versus mortality) and, therefore, the more vulnerable species (pines and spruce in the case of our study) might be more at risk than juniper (Anderegg et al., 2016).

In the particular case of Picea chihuahuana, our results indicate that, at least regarding resistance to cavitation, it is as vulnerable to drought stress as the three pines studied. Under climate change, this will put additional pressure on Picea chihuahuana, a species that is already endangered due to its narrow and fragmented distribution (Ledig et al., 2010), with some populations displaying signs of genetic erosion (Wehenkel and Sáenz-Romero, 2012). Severe droughtstress events due to climatic change may thus cause massive mortality in this species, as has already occurred in some spruce-dominated forest of the Rocky Mountains, USA (Bigler et al., 2007) and Norway (Solberg, 2004). However, considering that Picea chihuahuana as a whole is already endangered, a climatic change-linked massive mortality might eventually lead to extinction of the species.

\section{Future research needed}

Exploring resistance to cavitation in roots and leaves would provide complementary information to support our hydraulic trait results at branch level (see Domec et al., 2009; Domec et al., 2015), as well as examining cavitation resistance in the other two spruces represented in Mexico (Picea martinezii and Picea mexicana). Moreover, conducting measurements under natural or experimental drought stress conditions, such as over the range of water potentials experienced during critical heat waves and/or drought periods, would be of value to confirm the different abilities of each genus and species in terms of coping with the warmer and drier conditions predicted by the IPCC (2013). For quantifying the phenotypic plasticity of those traits, it would be advisable to conduct experiments including reciprocal transplantation, and to construct a response curve function to the climatic transfer distance (difference between the climate of the test site and climate of the seed source). Finally, the notion that juniper species might be more dominant than pine species in future climates than they are today, highlights the need for studying variability among juniper populations in terms of cavitation resistant traits, which to date have been studied mostly for pine species.

\section{Conclusions}

Our results confirm the greater vulnerability of three Mexican pine species and of Picea chihuahuana to cavitation compared to three species of the genus Juniperus. This higher vulnerability is particularly concerning in the case of Picea chihuahuana, an endemic and endangered species that presents a narrow and fragmented distribution. Our results suggest that, if the predicted climatic change does make the natural habitats of this species much warmer and drier, populations of Mexican pines and spruces will be likely to present severe decline, whereas the juniper species may survive. A process that would simplify the ensembles of natural species through a vegetation recomposition that is characterized by a more sparse tree coverage might then endanger the high biodiversity of the Mexican pine-oak and conifer forest, where pine species might die but juniper, which is more resistant to drought, will remain. 


\section{Acknowledgements}

Funding was provided to CSR by the joint research funds of the Mexican Council of Science and Technology (CONACyT), and the State of Michoacán (CONACyT-Michoacán, grant 2009-127128), a sabbatical year fellowship (at INRA-Cestas, France) from CONACyT (grant 232838) and the Coordinación de la Investigación Científica of the Universidad Michoacana de San Nicolás de Hidalgo (UMSNH), Mexico. Funding provided to CW was from CONACyT and the Ministry of Education (SEP; Project CB-2010-01-158054). This study was also supported by the program 'Investments for the Future' (ANR-10-EQPX-16, XYLOFOREST) from the French National Agency for Research to SD. NGM was supported by the Agreenskills fellowship program, which has received funding from the EU's Seventh Framework Program, under grant agreement FP7-26719 (Agreenskills contract). We thank Roberto Lindig-Cisneros, IIES-UNAM, Morelia and Miriam Garza-López, DiCiFo, Universidad Autónoma Chapingo, for their help with field collection, and Felipe López and Manuel Echevarria, of the Forestry Office of the Native Indian Community of Nuevo San Juan Parangaricutiro, Michoacán, for their help with seed and branch collection in their community forest. Assistance of Keith MacMillan as English reviewer significantly improved the manuscript.

\section{References}

Allen CD, Macalady AK, Chenchouni H, Bachelet D, McDowell N, Vennetier M, Kizberger T, Rigling A, Breshears DD, Hogg EH, Gonzalez P, Fensham R, Zhang Z, Castro J, Demidova N, Lim JH, Allard G, Running SW, Semerci A, Cobb N. 2010. A global overview of drought and heat-induced tree mortality reveals emerging climate change risks for forests. Forest Ecology and Management 259:660-684 doi:10.1016/j.foreco.2009.09.001

Allen CD, Breshears DD, McDowell NG. 2015. On underestimation of global vulnerability to tree mortality and forest die-off from hotter drought in the Anthropocene. Ecosphere 6(8) Article 129:1-55 doi:10.1890/ES15-00203.1

Anderegg WRL. 2014. Spatial and temporal variation in plant hydraulic traits and their relevance for climate change impacts on vegetation. New Phytologist 205:1008-1014 doi:10.1111/nph.12907

Anderegg WRL, Klein T, Bartlett M, Sack L, Pellegrini A, Choat B, Jansen S. 2016. Meta-analysis reveals that hydraulic traits explain cross-species patterns of drought-induced tree mortality across the globe. Proceedings of the National Academy of Sciences 113(18):5024-5029 doi:10.1073/pnas.1525678113

Bigler C, Gavin DG, Gunning C, Veblen TT. 2007. Drought induces lagged tree mortality in a subalpine forest in the Rocky Mountains. Oikos 116(12): 1983-1994 doi:10.1111/j.2007.0030-1299.16034.x

Bouche PS, Larter M, Domec JC, Burlett R, Gasson P, Jansen S, Delzon S. 2014. A broad survey of hydraulic and mechanical safety in the xylem of conifers. Journal of Experimental Botany 65 (15): 4419-4431 doi:10.1093/jxb/eru218

Breshears DD, Cobb NS, Rich PM, Price KP, Allen CD, Balice RG, Romme WH, Kastens JH, Floyd ML, Belnap J, Anderson JJ, Myers OB, Meyer CW. 2005. Regional vegetation die-off in response to global-change-type drought. Proceedings of National Academy of Sciences 102:15144-15148 doi:10.1073/pnas.0505734102

Breshears D D, Myers O B, Meyer C W, Barnes F J, Zou C B, Allen C D, McDowell NG, Pockman W T. 2009. Tree die-off in response to global change-type drought: Mortality insights from a decade of plant water potential measurements. Frontiers in Ecology and the Environment 7(4), 185-189 doi:10.1890/080016

Brodribb TJ, Cochard H. 2009. Hydraulic failure defines the recovery and point of death in water-stressed conifers. Plant Physiology 149:575-584 doi:10.1104/pp.108.129783

Brodribb TJ, Bowman DJMS, Nichols S, Delzon S, Burlett R. 2010. Xylem function and growth rate interact to determine recovery rates after exposure to extreme water deficit. New Phytologist 188: 533-542 doi:10.1111/j.1469-8137.2010.03393.x

Brodribb TJ, McAdam SAM, Jordana GJ, Martins SCV. 2014. Conifer species adapt to low-rainfall climates by following one of two divergent pathways. PNAS 111(40):14489-14493 doi:10.1073/pnas.1407930111

Carranza-González E, Zamudio S. 1994. Familia Cupressaceae. Flora del Bajío y de Regiones adyacentes, Fascículo 29.

Castellanos-Acuña D, Lindig-Cisneros RA, Sáenz-Romero C. 2015. Altitudinal assisted migration of Mexican pines as an adaptation to climate change. Ecosphere 6(1) Article 2:1-16

Choat B, Jansen S, Brodribb TJ, Cochard H, Delzon S, Bhaskar R, Bucci SJ, Feild TS, Gleason SM, Hacke UG, Jacobsen AL, Lens F, Maherali H, Martínez-Vilalta J, Mayr S, Mencuccini M, Mitchell PJ, Nardini A, Pittermann J, Pratt RB, Sperry JS, Westoby M, Wright IJ, Zanne AE. 2012. Global convergence in the vulnerability of forests to drought. Nature 491:752-756 doi:10.1038/nature11688

Cochard H. 2002. A technique for measuring xylem hydraulic conductance under high negative pressures. Plant Cell and Environment 25:815-819 doi:10.1046/j.1365-3040.2002.00863.x

Cochard H, Damour G, Bodet C, Tharwat I, Poirier M, Ameglio T. 2005. Evaluation of a new centrifuge technique for rapid generation of xylem vulnerability curves. Physiologia Plantarum 124:410-418 doi:10.1111/j.1399-3054.2005.00526.x

David-Schwartz R, Paudel I, Mizrachi M, Delzon S, Cochard H, Lukyanov V, Badel E, Capdeville G, Shklar G, Cohen S. 2016. Indirect evidence for genetic differentiation in vulnerability to embolism in Pinus halepensis. Frontiers in Plant Science 7, 768. doi:10.3389/fpls.2016.00768

Delzon S, Douthe C, Sala A, Cochard H. 2010. Mechanism of water-stress induced cavitation in conifers: bordered pit structure and function support the hypothesis of seal capillary-seeding. Plant, Cell and Environment 33(12):2101-2111 doi:10.1111/j.1365-3040.2010.02208.x

Development Core Team R. 2014. A language and environment for statistical computing. R Foundation for Statistical Computing, Vienna, Austria. Available: URL http://www.R-project: 
Domec, J-C, Noormets A, King JS, Sun G, McNulty SG, Gavazzi MJ, Boggs JL, Treasure EA. 2009. Decoupling the influence of leaf and root hydraulic conductances on stomatal conductance and its sensitivity to vapour pressure deficit as soil dries in a drained loblolly pine plantation. Plant, Cell \& Environment 32(8): 980-991. doi:10.1111/j.1365-3040.2009.01981.x

Domec, J-C, King JS, Ward E, Oishi AC, Palmroth S, Radecki A, Bell DM, Miao G, Gavazzi M, Johnson DM, McNulty SG, Sun G, Noormets A. 2015. Conversion of natural forests to managed forest plantations decreases tree resistance to prolonged droughts. Forest Ecology and Management 35: 58-71. doi:10.1016/j.foreco.2015.04.012

Intergovernmental Panel on Climatic Change (IPCC). 2013. Climate change 2013, the physical science basis. Contribution of Working Group I to the Fifth Assessment Report of the Intergovernmental Panel on Climate Change. Cambridge University Press, Cambridge

IUCN Red List of Threatened Species. 2015. Version 2015-3. <www.iucnredlist.org>. Accessed 23 September 2015.

Lamy J-B, Bouffier L, Burlett R, Plomion C, Cochard H, Delzon S. 2011. Uniform selection as a primary force reducing population genetic differentiation of cavitation resistance across a species range. PloS ONE 6(8):e23476 doi:10.1371/journal.pone.0023476

Lamy J-B, Delzon S, Bouche PS, Alia R, Vendramin GG, Cochard H, Plomion C. 2014. Limited genetic variability and phenotypic plasticity detected for cavitation resistance in a Mediterranean pine. New Phytologist. 201:874-886 doi: $10.1111 / \mathrm{nph} .12556$

Larter M, Brodribb TJ, Pfautsch S, Burlett R, Cochard H and Delzon S. 2015. Extreme aridity pushes trees to their physical limits. Plant Physiology 168(3):804-807 doi:10.1104/pp.15.00223

Ledig FT, Mápula-Larreta M, Bermejo-Velázquez B, Reyes-Hernández V, Flores-López C, Capó-Arteaga MA. 2000. Locations of endangered spruce populations in México and the demography of Picea chihuahuana. Madro-o 47:71-88

Ledig FT, Rehfeldt GE, Sáenz-Romero C, Flores-López C. 2010. Projections of suitable habitat for rare species under global warming scenarios. American Journal Botany 97(6): 970-987 doi:10.3732/ajb.0900329

Linton MJ, Sperry JS, Williams DG. 1998. Limits to water transport in Juniperus osteosperma and Pinus edulis: implications for drought tolerance and regulation of transpiration. Functional Ecology 12:906-911 doi:10.1046/j.1365-2435.1998.00275.x

Nixon KC. 1993. The genus Quercus in México. In: Ramamoorthy TP, Bye R, Lot A, Fa J (eds) Biological diversity of México: origins and distribution. Oxford Univ. Press, New York, pp 447-458

Nolf M, Beikircher B, Rosner S, Nolf A, Mayr S. 2015. Xylem cavitation resistance can be estimated based on time-dependent rate of acoustic emissions. The New Phytologist 208(2):625-632 doi:10.1111/nph.13476

Maherali H, Pockman WT, Jackson RB. 2004. Adaptive variation in the vulnerability of woody plants to xylem cavitation. Ecology 85(8):2184-2199 doi:10.1890/02-0538

Martínez-Vilalta J, Cochard H, Mencuccini M, Sterck F, Herrero A, Korhonen J F J, Llorens P, Nikinmaa E, Nolè A, Poyatos R, Ripullone F, Sass-Klaassen U, Zweifel R. 2009. Hydraulic adjustment of Scots pine across Europe. New Phytologist, 184(2), 353-364 doi:10.1111/j.1469-8137.2009.02954.x

Mátyás C. 2010. Forecasts needed for retreating forests. Nature 464:1271 doi:10.1038/4641271a

McDowell NG, Allen CD. 2015. Darcy's law predicts widespread forest mortality under climate warming. Nature Climate Change 5:669-672 doi:10.1038/nclimate2641

Pammenter NW, Van der Willigen C. 1998. A mathematical and statistical analysis of the curves illustrating vulnerability of xylem to cavitation. Tree Physiology 18:589-593 doi:10.1093/treephys/18.8-9.589

Peñuelas J, Oyaga R, Boada M, Jump AS. 2007. Migration, invasion and decline: changes in recruitment and forest structure in a warming-linked shift of European beech forest in Catalonia (NE Spain). Ecography 30:830-838

Pittermann J, Choat B, Jansen S, Stuart SA, Lynn L, Dawson TE. 2010. The relationships between xylem safety and hydraulic efficiency in the Cupressaceae: the evolution of pit membrane form and function. Plant Physiology 153:1919-1931 doi:10.1104/pp.110.158824

Quiñones-Perez CZ, Simental-Rodriguez SL, Saenz-Romero C, Jaramillo-Correa JP, Wehenkel C. 2014. Spatial genetic structure in the very rare and species-rich Picea chihuahuana tree community (Mexico). Silvae Genetica 63(4):149-159

Rehfeldt GE, Crookston NL, Warwell MV, Evans JS. 2006. Empirical analyses of plant-climate relationships for the western United States. International Journal Plant Science 167:1123-1150 doi:10.1086/507711

Rehfeldt GE, Crookston NL, Sáenz-Romero C, Campbell E. 2012. North American vegetation model for land use planning in a changing climate: a solution to large classification problems. Ecological Applications 22:119-141 doi:10.1890/11-0495.1

Sáenz-Romero C, Rehfeldt GE, Crookston NL, Pierre D, St-Amant R, Bealieau J, Richardson B. 2010. Spline models of contemporary, 2030, 2060, and 2090 climates for Mexico and their use in understanding climate-change impacts on the vegetation. Climatic Change 102:595-623 doi:10.1007/s10584-009-9753-5

Sáenz-Romero C, Lamy JP, Loya-Rebollar E, Plaza-Aguilar A, Burlett R, Lobit P and Delzon S. 2013. Genetic variation of drought-induced cavitation resistance among Pinus hartwegii populations from an altitudinal gradient. Acta Physiologiae Plantarum 35:2905-2913 doi:10.1007/s11738-013-1321-y

SAS Institute Inc. 2004. SAS/ STAT 9.1 User's Guide. SAS Institute Inc., Cary, North Carolina.

Solberg S. 2004. Summer drought: a driver for crown condition and mortality of Norway spruce in Norway. Forest Pathology 34(2):93-104 doi:10.1111/j.1439-0329.2004.00351.x

Styles BT. 1993. The genus Pinus: a México purview. In: Ramamoorthy TP, Bye R, Lot A, Fa J (eds) Biological diversity of México: origins and distribution. Oxford Univ. Press, New York, pp 397-420

Urli M, Lamy J-B, Sin F, Burlett R, Delzon S, Porté AJ. 2015. The high vulnerability of Quercus robur to drought at its southern margin paves the way for Quercus ilex. Plant Ecology 216:177-187 doi:10.1007/s11258-014-0426-8

Wehenkel C, Sáenz-Romero C. 2012. Estimating genetic erosion using the example of Picea chihuahuana Martínez. Tree Genetics and Genomes 8(5):1085-1094 doi:10.1007/s11295-012-0488-5 
Williams AP, Allen CD, Macalady AK, Griffin D, Woodhouse CA, Meko DM, Swetnam TW, Rauscher SA, Seager R, GrissinoMayer HD, Dean JS, Cook ER, Gangodagamage C, Cai, M McDowell NG. 2013. Temperature as a potent driver of regional forest drought stress and tree mortality. Nature Climate Change 3:292-297 doi:10.1038/nclimate1693

Willson CJ, Jackson RB. 2006. Xylem cavitation caused by drought and freezing stress in four co-occurring Juniperus species. Physiologia Plantarum 127:374-382 doi:10.1111/j.1399-3054.2006.00644.x 